\title{
Financial constraints and investment decisions of listed Indian manufacturing firms
}

Sanjeev Kumar ${ }^{*}$ and K. S. Ranjani

\author{
* Correspondence: \\ sanjeev.kumar.2014@nitie.ac.in \\ Department of Accounting and \\ Finance, National Institute of \\ Industrial Engineering (NITIE), \\ Mumbai, Maharashtra, India
}

\begin{abstract}
Background: The purpose of the study is to understand the role of cash flow sensitivity to investment as a measure of financial constraints among listed Indian manufacturing firms. It also analyses the role of tangibility in alleviating financial constraints. Further, the role of other financial factors in investment decisions is explored.
\end{abstract}

Methods: The study is conducted using the generalized method of moments (GMM) estimator on dynamic panel data for the period of (2009-2015) on 768 listed manufacturing firms.

Results: The analysis finds that cash flow sensitivity is a valid measure of financial constraints in the Indian manufacturing sector. Results according to splitting criteria found that investment decisions of standalone firms are more sensitive to cash flow than group affiliated firms. Further, splitting the firms according to market capitalization and tangible net worth reveals a higher degree of cash flow sensitivity by firms with lower market capitalization and asset tangibility. The results for the effects of tangibility of assets on easing financial constraint were found significant only in the case of firms with low tangible net worth and medium market capitalization.

Conclusions: The study confirms cash flow sensitivity to investment as a valid measure of financial constraints. It will confirm pooling of internal funds by financially constrained firms to accept profitable investment opportunities in future. Further, it also reports that asset tangibility eases the financial constraints faced by firms.

Keywords: Financial constraints, Investment determinants, Market capitalization, Tangible net worth, India, Generalized method of moments

\section{Background}

The basic requirement of firms is to fund investment projects by tapping the most economical source of financing. Firms can use internal finance, debt capital, or issue new equity to fund their projects. The popular pecking order theory suggests that the prioritization of funding sources by each firm is based on the cost it incurs, and accordingly, the first choice is internal finance, which is the most economical among the sources available. The next viable option is debt capital, followed by new equity issuance. The assumption of perfect capital markets reports that firms are able to raise enough external capital to finance profitable investment opportunities and cover any

(c) The Author(s). 2018 Open Access This article is distributed under the terms of the Creative Commons Attribution 4.0 International License (http://creativecommons.org/licenses/by/4.0/), which permits unrestricted use, distribution, and reproduction in any medium, provided you give appropriate credit to the original author(s) and the source, provide a link to the Creative Commons license, and indicate if changes were made. 
short-term cash flow shortages that may arise. However, capital markets in the real world are not perfect due to the presence of taxes, information asymmetry, agency problems, etc. This scenario gives rise to an important concept in corporate finance known as "financial constraints." The broad and established definition for this concept states that there exists a discrepancy between internal and external sources of finance, which precludes the company from making an investment it would have chosen to make, had internal funds been available (Kaplan \& Zingales, 1995). In other words, we can treat the inability of the firm to accept positive net present value projects due to inaccessibility of external finance as an example of financial constraints.

Under imperfect capital markets, firms face financial constraints and investment decisions in such markets are dependent on firm-level factors. The significance of these factors depends on the degree of information asymmetry faced by the firms. Cash flow sensitivity to investment is used as the proxy for capturing the extent of financial constraints by numerous studies, including the seminal contribution by Fazzari et al. (1988). However, its use as the most relevant proxy was challenged by Kaplan and Zingales (1995) and other studies that followed on theoretical, as well as interpretative grounds. To provide a solution for the proxy debate, Almeida (2007) suggested tangibility of assets as an alternative or facilitating measure to capture financial constraints; it gauges the effect of tangibility on cash flow sensitivity of investment through the tangibility credit multiplier approach. The present study is motivated by the desire to explore the variation in rates at which the external finance is available to the Indian firms, according to the characteristics of the firms seeking it. For example, the business group affiliation, tangibility of assets, and market capitalization influence the rates. Further, financial constraints as a topic of research interest is limited largely to the United States and European countries. Understanding the role of financial constraints in the Indian context becomes important due to the sharp differences in the interest rates at which external finance is available to the firms, as mentioned earlier. The objective of the study is to explore the investment determinants of firms by splitting firms according to firm-level criteria, such as business group affiliation, market capitalization, and tangible net worth. Further, it investigates the degree of cash flow sensitivity and the effects of tangibility on easing financial constraints. The motivation for conducting the present study is to understand the level of information asymmetry prevailing in the Indian capital market and the disparity among Indian firms in accessing external funds. The current study will contribute to the literature by reporting the extent of dependence on internal funds for the listed Indian manufacturing firms. It will also complement the dispersed literature on the use of a proxy for financial constraints, besides capturing the effects of pledging assets on alleviating the problem of financial constraints. The study will also provide evidence for the effects of financial constraints on investment decisions in developing economies, on which there are very few studies available.

\section{Literature review}

A key assumption of a perfect capital market is that internal and external finance are undifferentiated substitutes for financing investment opportunities (Modigliani and Miller, 1958). Further, it is assumed that the investment decisions of firms are independent of their capital structure because of the symmetrical availability of financing 
sources for all the firms. An alternative to the perfect capital market assumption is the perspective advanced in the work of Fazzari et al. (1988), who refute the view that internal and external finance are perfect substitutes in investment decisions. They provided empirical evidence for their study by using a sample of 422 U.S. manufacturing firms and distinguishing them on the basis of their dividend to income ratios. Firms that had the least payout efficiency were hypothesized as financially constrained ${ }^{1}$ and their investment decisions were found to be more sensitive to cash flows than those of unconstrained firms. According to this alternative viewpoint, a firm's investment will be a function of its financial factors and characteristics. A financially constrained firm will find it difficult to fund positive net present value projects due to the scarcity of internal funds and costly external finance. Later studies by Devereux and Schiantarelli (1990), Hoshi et al. (1991), T. Whited (1992), Wang (2003), Almeida et al. (2004), Denis and Sibilkov (2010), and Bhaumik et al. (2012) confirmed the findings of Fazzari et al. (1988). Carpenter et al. (1998), who compare three measures of financial constraints (cash-flow sensitivity, cash stocks, and coverage ratio), find evidence confirming cash flow as the preferred variable to test for the presence of financing constraints. Chapman et al. (1996) find that investment by Australian firms is less sensitive to cash flow when firms are financially unconstrained. Bo et al. (2003) use a sample of Dutch listed firms to indicate that the severity of financial constraints is greater for riskier firms and argue that investment cash flow sensitivity is a good proxy for financial constraints if firms are categorized by the level of uncertainty they face.

However, the findings of Fazzari et al. (1988) about internal and external capital being substitutes for each other were soon disputed by Kaplan and Zingales (1995), who reported inverse results and inefficiency in interpretation. They reported that the investments of financially unconstrained firms was more sensitive to cash flow and used the 10-k text ${ }^{2}$ of 49 U.S. firms to question the selection of cash flow sensitivity of investment as a measure of financial constraints. Further, studies by Kadapakkam et al. (1998), Cleary $(1999,2006)$, Erickson and Whited (2000), and Alti (2003) also supported the results of Kaplan and Zingales (1995). In a study on Japan, Dasgupta \& Sengupta (2007) find that the response of investment to cashflow shocks is non-monotonic, thereby supporting Kaplan \& Zingales (1995) and Cleary (1999).

In search of an alternate perspective for measuring financial constraints, Almeida et al. (2004) propose the "propensity of firms to save cash out of cash flows" (cash flow sensitivity of cash) as a proxy for liquidity constraints, because only constrained firms will manage liquidity to maximize their value. They test whether financially constrained firms exhibit higher cash-flow sensitivities than unconstrained firms. They find that financially constrained firms have a higher propensity to retain cash following negative macroeconomic shocks, while unconstrained firms do not show any such behavior. Extending the above result, Almeida and Campello (2007) tested the effect of tangibility of assets on investment by the firms. The study used cash flow and asset tangibility multiplier to find out the marginal effect of asset tangibility on cash flow sensitivity to investment.

However, to the best of our knowledge, there is no study which considers the effect of all these factors taken together. Hence, the current study empirically 
investigates cash flow sensitivity to investment and discusses the effects of asset tangibility, along with sales and leverage, to test the validity of the measures discussed above for the Indian manufacturing sector. Table 1 lists selected studies analyzing the role of cash flow sensitivity to investment around the globe, arranged in chronological order. It also includes their methodology, criteria for the a priori classification of firms into financially constrained and unconstrained firms, and findings.

\section{Empirical estimation framework}

The amount of external capital required at any given time by the financially constrained firm can be given by $\varphi$, which is a function of the debt capacity and other financial factors of the firm.

$$
\varphi=F(\tau, \text { financial factors })
$$

where $\tau$ is the debt capacity of the firm. The unconstrained firm faces two scenarios. Either the amount of internal funds available to the firm $(\omega)$ is in excess of the current demand $\pi$ or the availability of external funds satisfies current demand. Suppose $\pi$ is the funding requirement for the new investment opportunity that is available.

$\pi<\omega$ or $\phi \notin \tau$ (external funds available, irrespective of tangibility of assets) Borrowing constraints for financially constrained firm can be given by creditor's liquidation value of the firm ( $\mathrm{\tau l})$.

$$
\pi<\tau l \text {. }
$$

Hence, according to Almeida and Campello (2007), cash flow sensitivity to investment for financially constrained and unconstrained firms can be written as

$$
\begin{aligned}
& \frac{\partial I}{\partial w}(w, \tau)=\frac{1}{1-\tau} \text { for financially constrained firms } \\
& \frac{\partial I}{\partial w}(w, \tau)=0 \text { for financially unconstrained firms }
\end{aligned}
$$

The cash flow sensitivity will decrease with the increase in the tangibility of assets to the firm for the financially constrained firm, that is, tangibility will result in easing the financial constraints on the firm. For the unconstrained firms, investment will be independent of the fluctuations in cash flows. Thus tangibility will be irrelevant to the investment of the financially unconstrained firm. The empirical estimation framework is built using this assumption and other financial factors to investigate whether cash flow sensitivity is a valid measure of financial constraints. Further, the role of asset tangibility on the firms is explored.

To identify the role of cash flow sensitivity to investment in measuring financial constraints, we use sales accelerator model proposed by Abel and Blanchard (1986). According to the model, an increase in a firm's sales leads to increasing firm investment along with other financial factors. The model is further extended to understand the influence of tangibility on cash flow sensitivity to investment in Eq. 1. 
Table 1 Studies analyzing the role of cash flow sensitivity to investment around the globe

\begin{tabular}{lll}
\hline Author & Segmenting variables & Methodology \\
\hline $\begin{array}{l}\text { Fazzari et al. } \\
\text { (1988) }\end{array}$ & Dividend pay-out & $\begin{array}{l}\text { Ordinary least square } \\
\text { regression }\end{array}$ \\
$\begin{array}{l}\text { Devereux \& } \\
\text { Schiantarelli (1990) }\end{array}$ & Age, size, age + size & $\begin{array}{l}\text { Ordinary least square } \\
\text { regression }\end{array}$ \\
& & \\
$\begin{array}{l}\text { Hoshi, Kashyap \& } \\
\text { Scharfstein (1991) }\end{array}$ & $\begin{array}{l}\text { Business group } \\
\text { affiliation }\end{array}$ & $\begin{array}{l}\text { Ordinary least square } \\
\text { regression }\end{array}$
\end{tabular}

Findings

Cash flow sensitivity is significant for

low pay-out firms and insignificant

for high pay-out firms.

T. Whited (1992) Interest coverage ratio

Scharfstein (1991)

Hubbard, Kashyap, and Whited (1995)

Bond \& Meghir (1994)

Chiriko \& Schaller (1995)

Gilchrist \&

Himmelberg (1995)

Kaplan \& Zingales (1995)

Kadapakkam, Kumar, \& Riddick (1998)

Cleary (1999)

Lensink, der Molen, \& Gangopadhyay (2003)
Dividend pay-out

Dividend over capital stock+ Share issues

Age, concentration of ownership, Business group affiliation

Dividend pay-out ratio, size and existence of bond rating

Dividend pay-out

Size

Ordinary least square regression

Financial status index

Business group affiliation

Linear Regression with GMM

Generalized method of moments and hierarchy of finance model

Ordinary least square regression

Generalized method of moments and simple regression

Ordinary least square regression

regression and multiple discriminant analysis and GMM estimation
Linear Regression

with GMM estimator cash flow when size is splitting criteria and when firms are segmented on the basis of age cash flow is more important for newer firms than older ones.

Investment is more sensitive to the group of firms for which the lender has less information available. It also highlights role of intermediaries in the investment process.

Financial constraints significantly affects the firm that do not participate in the bond market. Financial variables affects constrained firms much more than unconstrained firms.

Capital market imperfections effects investment decisions

Current investment is positively related to lagged cash flows even after controlling for output fluctuations (Imperfect competition) and debt (bankruptcy cost -taxes).

Firms in weak information positions due to ownership structure, group membership and age have larger coefficients to liquidity even after correcting for endogeneity

Similar behaviour of large and small firms under the assumption of financial constraints.

Cash flow sensitivity is larger for unconstrained firms rather than constrained firms which contradicts results of Fazzari et al. (1988)

The cash flow sensitivity is highest in the large firm size group and smallest in the small firm size group. It is also reported that cash flow sensitivity is independent of the measure of firm size.

Least constrained firms are more sensitive to cash flow sensitivity to investment.

Regression with OLS
The study reports that there is a significantly positive group affiliation effect: stand-alone companies have higher cash flow sensitivities than group affiliates. It also finds that there is a significant impact of firm size on the cash flow sensitivity of firm investment. A larger firm typically has a higher cash flow coefficient. Another result is the effect of a firm's age: we find some evidence that younger firms have lower cash flow coefficients. 
Table 1 Studies analyzing the role of cash flow sensitivity to investment around the globe (Continued)

\begin{tabular}{|c|c|c|c|}
\hline Author & Segmenting variables & Methodology & Findings \\
\hline Wang (2003) & $\begin{array}{l}\text { Stochastic frontier } \\
\text { modelling }\end{array}$ & $\begin{array}{l}\text { Stochastic frontier } \\
\text { modelling }\end{array}$ & $\begin{array}{l}\text { Cash flows will not only promote the } \\
\text { rate of investment in an environment } \\
\text { of financing constraints, but they also } \\
\text { has a strong effect on reducing the } \\
\text { variance of financing constraints }\end{array}$ \\
\hline
\end{tabular}

Almeida,

Campello, \&

Weisbach (2004)

vidend pay-out, size

bond ratings,

commercial paper

ratings, Kaplan-

Zingales index

Cleary (2006)

Size, dividend pay-out ratio and Financial status index

Synthetic index

T. M. Whited \& Wu (2006)

Almeida \& Campello (2007)

Denis \& Sibilkov
Asset tangibility, dividend pay-out, size, bond ratings, commercial paper ratings inary least square regression

Ordinary least square regression and multiple discriminant analysis

Regression with GMM estimator

Switching regression and generalized method of moments (2010)

Campello, Graham, \& Harvey (2010)

Dividend pay-out, firm size, Bond rating commercial paper rating

Survey data

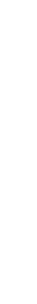

Bhaumik et al. (2012)
Stochastic frontier modelling
Ordinary least square regression

Ordinary least square regression
Stochastic frontier modelling
Financially constrained firms have higher propensity to retain cash following negative macroeconomic shocks, while unconstrained firms do not show any such relation.

The results suggests that the investment decisions of firms with stronger financial positions are much more sensitive to the availability of internal funds than those that are less creditworthy confirming with the results of Kaplan \& Zingales, (1995) and Cleary, (1999).

The study reports evidences that firm-level external finance constraints do indeed represent a source of undiversifiable risk that is priced in financial markets.

The study reports that while asset tangibility increases investment-cash flow sensitivities for financially constrained firms, no such effects are observed for unconstrained firms. It also highlights tangibility of assets influences a firm's credit status according to theoretical expectations: firms with more tangible assets are less likely to be financially constrained.

The results indicate that higher cash holdings are associated with higher levels of investment for constrained firms with high hedging needs and that there is a significantly stronger positive association between investment and value for constrained than for unconstrained firm.

The study finds that that financially constrained firms plan to cut more investment, technology, marketing, and employment relative to financially unconstrained firms during the crisis. It also shows that constrained firms are forced to burn a sizeable portion of their cash savings during the crisis and to cut more deeply planned dividend distributions. In contrast, unconstrained firms do not display this behaviour.

Financial constraints in India are alleviated by cash flows and (log) assets of firms, and aggravated by a high leverage level. We also find that business groups alleviate credit constraints for member firms, but their ability to do so has declined over time. 
Table 1 Studies analyzing the role of cash flow sensitivity to investment around the globe (Continued)

\begin{tabular}{|c|c|c|c|}
\hline Author & Segmenting variables & Methodology & Findings \\
\hline $\begin{array}{l}\text { Bavarsad et al. } \\
\text { (2013) }\end{array}$ & Kaplan-Zingales Index & Linear regression & $\begin{array}{l}\text { Small firms faces more financial } \\
\text { constraints than larger firms. }\end{array}$ \\
\hline $\begin{array}{l}\text { Črnigoj, M., \& } \\
\text { Verbič, M. (2014) }\end{array}$ & $\begin{array}{l}\text { EBITDA, Interest } \\
\text { coverage ratio, Size } \\
\text { log (sales) and the } \\
\text { level of financial slack }\end{array}$ & $\begin{array}{l}\text { Generalized method } \\
\text { of moments and } \\
\text { switching regression }\end{array}$ & $\begin{array}{l}\text { During the time of financial crisis in } \\
\text { Slovenian firms in } 2009 \text { both } \\
\text { financially constrained and } \\
\text { unconstrained firms were effected } \\
\text { but the smaller firms were more } \\
\text { affected than middle and large size } \\
\text { firms. Financially constrained firms } \\
\text { are more cash flow sensitive to } \\
\text { investment. }\end{array}$ \\
\hline Stucki (2014) & Survey data & Probit model & $\begin{array}{l}\text { Firm survival and the achievement of } \\
\text { profit break-even are negatively } \\
\text { correlated with financial constraints. } \\
\text { With increasing firm age, the impact } \\
\text { of financial constraints on the } \\
\text { survival probability disappears. The } \\
\text { negative effect on the probability to } \\
\text { achieve profit break-even, however, } \\
\text { remains statistically significant. }\end{array}$ \\
\hline Ameer (2014) & $Q$ ratio and debt ratio & $\begin{array}{l}\text { Panel smooth } \\
\text { transition and } \\
\text { switching regression }\end{array}$ & $\begin{array}{l}\text { The study suggests that investment } \\
\text { is not only sensitive to cash flows } \\
\text { but also to business cycle and } \\
\text { tangibility of assets for the Asian } \\
\text { firms. }\end{array}$ \\
\hline
\end{tabular}

The table represents selected studies in chronological order that studies cash flow sensitivity to investment and financial constraints along with the methodology and splitting criteria used for analysis

$$
\begin{aligned}
\left(\frac{I}{K}\right)_{i, t} & =a o+\rho\left(\frac{I}{K}\right)_{i, t-1}+\beta_{1}\left(\frac{\Delta S}{K}\right)_{i, t}+\beta_{2}\left(\frac{C F}{K}\right)_{i, t}+\beta_{3}\left(\frac{D}{K}\right)_{i, t}+\beta_{4} L n \text { tangibility } \\
& +\beta_{5}\left(\text { Ln tangibility }{ }_{i, t} \times\left(\frac{C F}{K}\right)_{i, t}\right)+u_{i, t}+e_{i, t}
\end{aligned}
$$

where $I$ represents firm investment (change in gross fixed assets); $S$ represents a change in firm sales or output as a measure of future profitability and growth opportunities; CF represents the sum of cash flows, net income, depreciation, and amortization; D represents the total borrowings in addition to preference share capital; and $u_{i}$, represents the idiosyncratic error term. $\mathrm{K}$ is the firm's beginning of the period capital stock calculated according to the specification used by Fazzari et al. (1988), as shown in Eq. 2.

$$
K_{i, t}=\frac{P_{t}}{P_{t-1}}\left[I_{i, t-1}+K_{i, t-1}\left(1-\frac{1}{L}\right)\right]
$$

where $K_{\mathrm{i}}$, is the capital stock for the firm $\mathrm{i}$ at time $\mathrm{t}$ and $P_{\mathrm{t}}$ is the GDP deflator at factor cost for the manufacturing firms, by taking 2004-2005 as the base year. $I_{\mathrm{i}},-1$ is the lagged investment and $\mathrm{L}$ is average service life of the firm.

\section{Sample splitting criteria}

To study the effects of financial constraints, we require an appropriate splitting criteria to categorize the firms. By splitting firms into groups with different levels of asymmetric 
information, we can investigate the impact of asymmetric information and agency problems on firms with different characteristics. The selection of relevant criteria is also important because the existing literature points out that the cash flow sensitivity of investment is susceptible to the factors used to split the firms. Hence, we need to identify the criteria that allow us to interpret the availability of firms' internal funds in the Indian context. We use the following three criteria to split the firms into financially constrained and unconstrained firms:

- Ownership status of the firm

- Size of firms.

- Debt Capacity of the firms.

The reason for selecting ownership classification as the criteria for splitting the firms is that the firms with group affiliation have easier access to internal funds than standalone firms. Business groups are particularly effective in dealing with information and contract enforcement problems within the groups. When a firm needs external finance, it can obtain funds at a relatively lower cost (Byun et al., 2013). Using a Japanese dataset, Hoshi, Kashyap, and Scharfstein (1991) find that firms that are part of the industrial groups display lower cash flow sensitivities. Evidence from other countries, such as Korea (Shin and Park 1999) and Canada (Schaller 1993; Chirinko and Schaller 1995) also lends support to the idea that affiliation to industrial groups helps to reduce information asymmetries and relax financial constraints.

Therefore, it is expected that firms which have an affiliation to industrial groups will have a lower investment to cash flow sensitivities than firms who are not; this is because of the reduction in information costs by virtue of being part of the group and the access to its internal capital. Moreover, this sample splitting criterion is particularly desirable because the status of affiliation to industrial groups tends to be fixed, which avoids the problem of endogeneity. The evidence of investment-cash flow sensitivities tends to be quite robust if the affiliation to the industrial group is used as a sorting criterion. Market capitalization is used as the splitting criteria based on the study by Lamont et al. (2001), where it is used as the proxy for size. Market capitalization is also used as the proxy for calculating Tobin's Q values of the firm in the Kaplan-Zingales index, as described in Lamont et al. (2001). Market capitalization of the firm is very important in the Indian context as it reflects the liquidity of the stock and also reflects the awareness about the firm among the investors.

Similarly, tangible net worth can be seen as the amount of collateral that a firm can use to borrow external funds. The tangibility of assets and debt capacity enables the firm to have easier access to external funds. The study conducted by Almeida and Campello (2007) reported that asset tangibility increases cash flow sensitivity for financially constrained firms. Based on the above study, we are using tangible net worth as a proxy for assets that can be pledged in the Indian context.

\section{Data and methodology}

In our study, the data is extracted from the Prowess database of the Centre for Monitoring Indian Economy (CMIE).This is the largest database for firm-level data related to Indian companies. The data is taken from the annual reports, financial 
statements, and other published reports of the Indian firms. The database has over 26,000 Indian firms from various sectors of the economy.

Data is extracted for a seven-year period (2009-2015) for all the listed ${ }^{3}$ manufacturing firms available in the CMIE database. The final analysis is performed for the 2010-2015 period, as data for 2009 is used only to finalize the variables included in the study. The proxies used for the variables have been highlighted in Table 2.

There are total of 1034 firms across different industries under manufacturing sector. Further, data is cleaned based on various filters to improve the efficiency and validity of the results.

The cleaning is performed by taking the following steps:-

1. Firms with missing data for three or more years on investment or capital stock are removed from the analysis.

2. Firms for which data on market capitalization or tangible net worth is missing are removed from the analysis. There are two reasons for doing this. First, market capitalization and tangible net worth are used as the criteria for splitting firms into various groups. Second, firms without data on market capitalization might have been delisted or ceased to exist. Further, some firms that have ceased to exist are not dropped from the CMIE database.

3. Firms with negative tangible net worth are removed from the analysis because of the deficit on the asset side. The firms in this situation will not be able to tap financing opportunities and will experience subdued business growth. Hence, the presence of these firms will carry bias in the results.

4. Firms that merged with some other firm were also removed from the analysis.

The application of the above filters reduced the number of firms to 768. The mean statistics for these are provided in terms of the splitting criteria used to classify the variables into financially constrained and unconstrained firms in Table 3. There are a total 13,824 observations for the five variables calculated for six years. The data is also tested for multicollinearity using the variance inflation factor (VIF) test. VIF values greater than 10 are indicative of the multicollinearity in the data that needs to be resolved before analysis (Craney and Surles, 2002). The values of the variables used in

Table 2 Proxy for variables

\begin{tabular}{|c|c|}
\hline Variable & Proxy used \\
\hline Investment & $\begin{array}{l}\text { Gross fixed assets additions - Gross fixed assets deductions for the } \\
\text { year (In millions). }\end{array}$ \\
\hline Change in sales & Sales n - Sales n-1 (In millions). \\
\hline Cash flow & Profit after tax +Depreciation +Amortisation for the year. \\
\hline Leverage & Total borrowings + preference share capital \\
\hline Replacement value of Capital stock & $\begin{array}{l}\text { Gross fixed assets subject to the specification used by } \\
\text { (Fazzari et al., 1988; Atheny and Laums, 1994; Bhaduri, 2005) }\end{array}$ \\
\hline GDP implicit price deflator & $\begin{array}{l}\text { RBI data on GDP implicit price deflator for manufacturing firms } \\
\text { subject to base year 2004-2005. }\end{array}$ \\
\hline Average service life of the firm & 16 years (Bhaduri, 2005) \\
\hline Size & Market capitalization \\
\hline Debt capacity & Tangible net worth (Net worth - Intangible net worth) \\
\hline
\end{tabular}




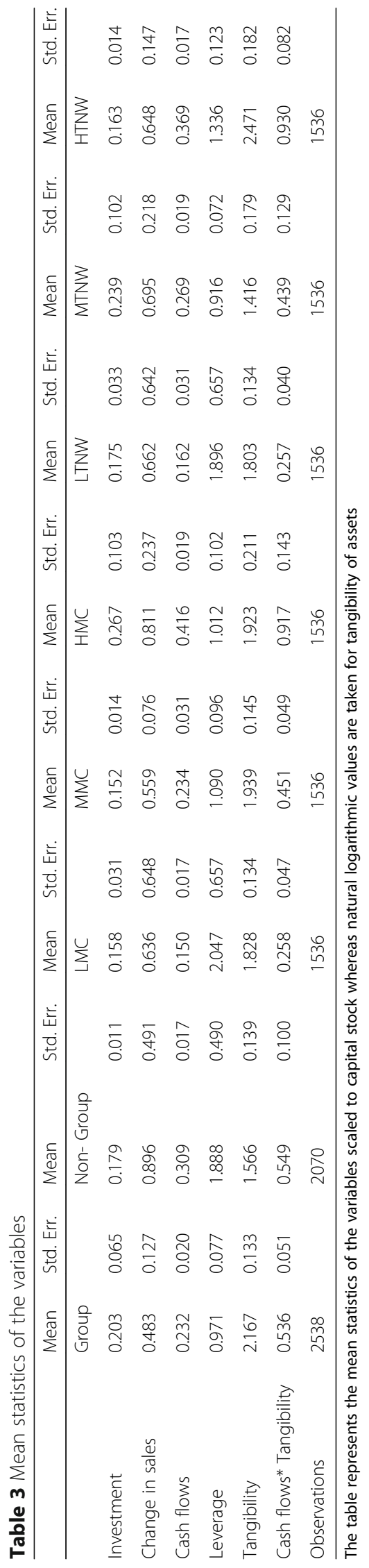


the study are found to be within limits, with an average VIF of 2.23 and maximum value of 3.15 reported for the interaction variable of cash flow and tangibility of assets. The VIF values for independent variables are reported in Table 4. The compiled correlation matrix for the explanatory variables is presented in Table 5.

The cleaned data is then classified on the basis of the splitting criteria chosen for the study. First, the firms are divided on the basis of business group affiliation that divides the data into 423 firms associated with business groups and 345 standalone firms. Second, firms are divided on the basis of market capitalization, which is taken as the proxy for size. Accordingly, the firms are divided into the following three groups, in decreasing order of market capitalization: high market capitalization (HMC); medium market capitalization (MMC); and low market capitalization (LMC). There are 256 firms in each of these groups. Similarly, the third criterion for the division of firms is the tangible net worth, taken as the proxy for debt capacity. Firms are divided into the following three groups, in decreasing order of tangible net worth: high tangible net worth (HTNW); medium tangible net worth (MTNW); and low tangible net worth (LTNW). Here too, there are 256 firms in each group. Another important restriction that we applied to the data is prohibiting a shift to some other during the period of analysis. Thus, a firm belonging to the LMC group will not be changed to MMC or $\mathrm{HMC}$ with time. A similar restriction applies for the firms grouped according to the other two criteria.

Finally, each group is analyzed using the Generalized Method of Moments (GMM) for one- and two-step estimators, as specified by Arellano and Bond (1991) for the dynamic panel data model. The proposed sales accelerator model can be considered as a dynamic panel data equation where the lags of the dependent variable along and the other variables are taken as an independent variable to verify the cash flow sensitivity of investment. The advantage of using GMM is the efficient results which it brings by taking the unobserved heterogeneity into account when estimating the first order equation. Further, second order GMM can be used to improve the result of first order estimates due to the asymptotic efficient estimates. Also, endogeneity problems are taken care of by using lag of dependent variable as instruments. We allowed maximum one lag of dependent variable to be used as instruments in most of the groups, except a few which used more instruments for the analysis. The autoregression of order AR (2) was used in the analysis. To find if the model is appropriate, robustness checks were performed using Arellano and Bond (1991) test for autocorrelation (H0-no autocorrelation) and the Sargan (1958) test for the validity of over-identifying restrictions (H0-over identifying restrictions are valid). The results are reported after checking for any lacunae in the model. The final results are reported according to GMM second order considering the efficiency that it brings to the estimates.

Table 4 Multicollinearity test (VIF)

\begin{tabular}{lll}
\hline Independent variables & VIF & 1 NIF \\
\hline Change in sales & 1.91 & 0.522219 \\
Cash Flow & 1.32 & 0.758013 \\
Leverage & 1.92 & 0.520692 \\
Tangibility & 2.85 & 0.35082 \\
Cash flow* Tangibility & 3.15 & 0.317636 \\
\hline
\end{tabular}


Table 5 Compiled correlation matrix for the independent variables

\begin{tabular}{llllll}
\hline Independent variables & Change in sales & Cash flow & Leverage & Tangibility & Cash flow* Tangibility \\
\hline Change in sales & 1 & & & & \\
Cash Flow & -0.0249 & 1 & & & \\
Leverage & -0.6832 & -0.0735 & 1 & & \\
Tangibility & 0.0205 & 0.2934 & -0.0037 & 1 & \\
Cash flow* Tangibility & -0.0346 & -0.4716 & 0.0087 & -0.6314 & 1 \\
\hline
\end{tabular}

\section{Findings and discussion}

The findings are reported in accordance with the splitting criteria (ownership group, size, and debt capacity) used for the analysis. The model is reported significant and appropriate for all the groups on which analysis is performed. The results for firms according to the a priori classification are highlighted in Table 6 in detail. The results for group firms suggest that sales and debt are positively significant, while cash flow is negatively significant in the first order GMM analysis. In the second order analysis, lagged investment is also found significant, along with the above variables. The results from non-group firms show that only cash flow is the significant variable in both the first and second order analysis. This shows that investment of standalone firms was more sensitive to cash flow sensitive than that of group affiliated firms. Further, a negative coefficient for cash flows for group firms suggests surplus cash flows that are much larger than investment opportunities available with these firms. Further, sales and capital structure are found to be key determinants of investment in group affiliated firms.

Furthermore, robustness checks are performed by using Arellano and Bond (1991; also called AR [1] and AR [2] tests) and Sargan (1958) tests for testing autocorrelation and the results suggest that there is no autocorrelation in the model. AR (1) and AR (2) test represents the null hypotheses (H0-zero autocorrelation) in first differenced errors for the first order analysis and second order analysis, respectively. The $p$-values

Table 6 Results business group classification

\begin{tabular}{|c|c|c|c|c|c|c|c|c|}
\hline \multirow[b]{3}{*}{ Investment } & \multicolumn{4}{|l|}{ Group firms } & \multicolumn{4}{|c|}{ Non-group firms } \\
\hline & \multicolumn{2}{|c|}{ One step estimator } & \multicolumn{2}{|c|}{ Two step estimator } & \multicolumn{2}{|c|}{ One step estimator } & \multicolumn{2}{|c|}{ Two step estimator } \\
\hline & Coefficient & Std. Err. & Coefficient & Std. Err. & Coefficient & Std. Err. & Coefficient & Std. Err. \\
\hline Lagged investment & -0.00559 & 0.004 & $-\overline{0.00553^{* * *}}$ & 0.000 & -0.04022 & 0.039 & 0.026228 & 0.027 \\
\hline Change in sales & $0.287974^{* * *}$ & 0.003 & $0.280323^{* * *}$ & 0.006 & 0.000919 & 0.000 & 0.000969 & 0.001 \\
\hline Cash flow & $-0.48834^{* * *}$ & 0.022 & $-\overline{0.48835^{* * *}}$ & 0.023 & $0.228716^{* * *}$ & 0.046 & $0.201292^{* *}$ & 0.087 \\
\hline Leverage & $0.698807^{* * *}$ & 0.011 & $0.655403^{* * *}$ & 0.021 & 0.000739 & 0.001 & 0.000628 & 0.002 \\
\hline Tangibility & -0.00688 & 0.007 & $-0.01444^{* *}$ & 0.005 & 0.00476 & 0.009 & 0.006577 & 0.010 \\
\hline $\begin{array}{l}\text { Cash flow* } \\
\text { Tangibility }\end{array}$ & 0.021803 & 0.019 & $0.04987^{* * *}$ & 0.018 & -0.00684 & 0.014 & -0.00999 & 0.017 \\
\hline Constant & $-0.51621^{* * *}$ & 0.021 & $-0.47418^{* * *}$ & 0.058 & $0.108221^{* * *}$ & 0.025 & $0.091152^{* * *}$ & 0.028 \\
\hline AR 1 & - & - & .1812 & - & - & - & .0006 & - \\
\hline AR 2 & - & - & .1630 & - & - & - & .2200 & - \\
\hline Sargan statistics & .000 & - & .4215 & - & 0.0711 & - & .1981 & - \\
\hline
\end{tabular}

The table represents results using business group affiliation as the priori classification for dividing firms. AR1 and AR2 represent Arellano and Bond test (1991) for autocorrelation in first difference errors. Sargan test for the over-identifying restriction is also highlighted in the table. ${ }^{* * *}, *^{* *}$, represents significance at $99 \%, 95 \%$ and $90 \%$ respectively 
reported for AR (1) and AR (2) are 0.1812 and 0.1630 , respectively; these preclude the rejection of the null hypothesis for group firms. Similarly, panel for standalone firms has reported no evidence for appropriateness of the model. Further, Sargan test fails to provide any evidence for autocorrelation, with p-values of .4215 and .1981 for group affiliated firms and standalone firms, respectively.

The results according to size (market capitalization) report the highest cash flow sensitivity to investment with coefficients of (1.5162) and (0.6363) for LMC firms for one-step estimators and two-step estimators, respectively. All other variables, besides cash flow, reported an insignificant relationship with investment. Further, MMC firms report negative cash flow sensitivity to investment with a coefficient $(-0.1258)$ in the first order and a coefficient of $(-0.1795)$ in the second order. Sales, debt and lagged investment are also found to have a significant relationship between investments, along with cash flow, in the case of the MMC firms. However, HMC firms report an insignificant relation between cash flows and investment. Debt is found as the most important determinant that positively influences investment, along with a marginal positive impact from sales in the first order analysis. Second order analysis found no significant influence of sales but reported negative influence $(-0.0037)$ of lagged investment on the HMC firms' investment. Tests for checking validity reject the null hypotheses; hence, autocorrelation in the model can be ruled out. Above findings suggest that cash flow sensitivity to investment is inversely proportional to the size of the firm. Thus, the smaller the firm, the higher will be its cash flow sensitivity to the investment for the firms. The detailed results are provided in Table 7.

The results obtained by splitting the firms by debt capacity (tangible net worth) are quite similar to those based on splitting according to size. LTNW firms report significant positive influence of cash flows on investment whereas all the other variables report an insignificant relationship with investment. MTNW firms reported significant positive relationship with investment for all the variables except cash flows, for which a negative influence is reported. Further, HTNW firms report a significant relationship between cash flows and investment in the first order but the results from second order estimates rule out any significant relationship. Sales and debt are also found significant in the first order analysis but not in the second order analysis. The model reports no autocorrelation for robustness checks in the analysis. Hence, we can say that cash flow sensitivity to investment reduces with the increase in debt capacity of the firms. Table 8 highlights the key results of the analysis.

\section{Conclusions}

The study explores the investment behavior pursuant to characteristics of the firms and analyzes the effect of tangibility of assets in allevisating financial constraints. The results report significant firm factors to investment by splitting the firms using the a priori splitting criteria for the firms according to business group affiliation, market capitalization, and tangible net worth. Standalone firms are found to be more cash flow sensitive to investment in comparison to group affiliated firms, highlighting both their strong dependence and scarcity of internal funds for investment decisions. Cash flow is found to be the only significant factor while taking investment decisions for the standalone firms whereas sales and capital structure were found to be crucial in the investment decisions for group affiliated firms. The results from splitting the firms 


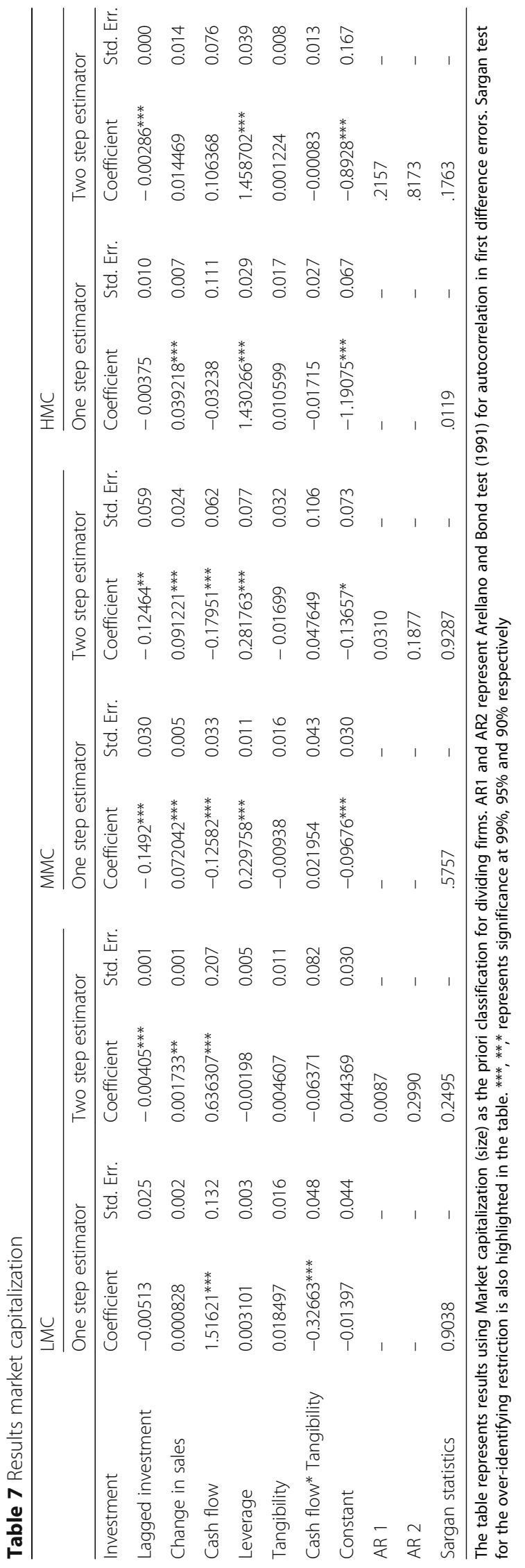




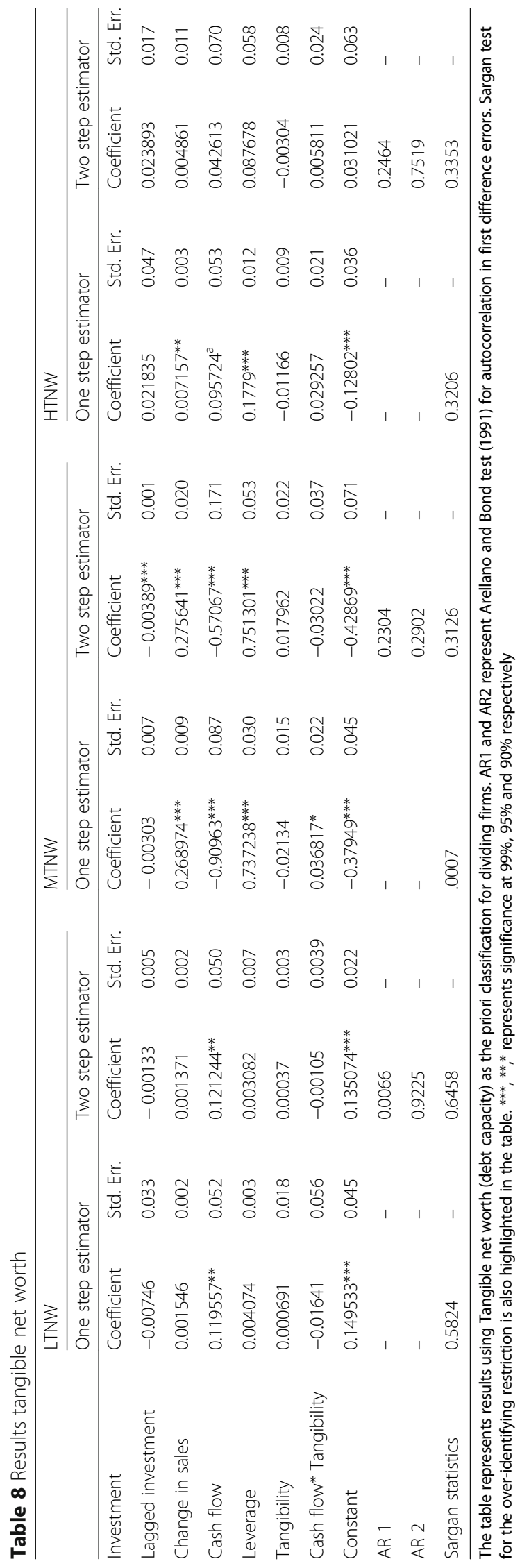


according to market capitalization and tangible net worth reveal a higher degree of cash flow sensitivity for firms with lower market capitalization and tangibility of assets. Findings of the study also suggest that medium market capitalization firms experience the combined effect of many variables on their investment decisions as all the variables report significant relationship with investment. The results for effects of tangibility of assets on easing financial constraint were found to be significant only for low tangible net worth and low market capitalization firms.

To summarize, the results provide sufficient evidence to highlight the importance of internal funds and elucidates the prevailing discrepancies in availability of external finance in the Indian capital markets. Further, the tangibility of assets is found to contribute significantly to the investment by financially constrained firms; however, it is not found to be relevant for financially unconstrained firms. The study provides supporting evidence that cash flow sensitivity as a suitable measure of financial constraints - earlier applied mostly to developed economies - and will have implications for other developing economies. Furthermore, the role of tangibility and other investment determinants can help researchers to build future research that incorporates the context of developing economies.

The study is limited to Indian listed manufacturing firms due to the defined objectives and nature of variables chosen for the study. However, a large number of private firms are not taken into account in this study. Future research can be conducted on the private firms in developing economies with an extended set of variables. Such studies can further validate the role of financial constraints and derive managerial implications for a large spectrum of firms in different sectors of developing economies.

\title{
Endnotes
}

${ }^{1}$ In an imperfect capital market where characteristics of the firm will influence the acceptance of investment opportunities, firms that fail to fund positive NPV projects due to asymmetry between internal and external funds will be called as financially constrained firms.

${ }^{2}$ Annual financial report of U.S. companies required by Securities and Exchange Commission highlighting financial performance of firms.

${ }^{3}$ Listed on Bombay stock exchange.

\begin{abstract}
Abbreviations
AR: Auto regression; CMIE: Centre for Monitoring Indian economy; GDP: Gross Domestic Product; GMM: Generalized Method of Moments; HMC: High Market Capitalisation; HTNW: High Tangible Net Worth; LMC: Low Market Capitalization; LTNW: Low Tangible Net Worth; MMC: Medium Market Capitalization; MTNW: Medium Tangible Net Worth; VIF: Variance Inflation Factor
\end{abstract}

Acknowledgements

The authors are grateful to the anonymous referees of the journal for their extremely useful suggestions to improve the quality of the article. The usual disclaimer applies.

Funding

This research received no specific grant from any funding agency in the public, commercial, or not-for-profit sectors.

Authors' contributions

We have no conflicts of interest to disclose. Both the authors contributed equally to this work. Both authors read and approved the final manuscript. 
Received: 8 April 2017 Accepted: 28 February 2018

\section{Published online: 15 March 2018}

\section{References}

Abel A B, Blanchard O J (1986) Investment and sales: Some empirical evidence. (No. w2050), National Bureau of Economic Research

Almeida H, Campello M (2007) Financial constraints, asset tangibility, and corporate investment. Rev Financ Stud 20(5):1429-1460

Almeida H, Campello M, Weisbach MS (2004) The cash flow sensitivity of cash. J Financ 59(4):1777-1804

Alti A (2003) How sensitive is investment to cash flow when financing is frictionless? J Financ 58(2):707-722

Ameer R (2014) Financial constraints and corporate investment in Asian countries. Journal of Asian Economics, Elsevier Inc 33:44-55

Arellano M, Bond S (1991) Some tests of specification for panel data: Monte Carlo evidence and an application to employment equations. Rev Econ Stud 58(2):277-297

Athey MJ, Laumas PS (1994) Internal funds and corporate investment in India. J Dev Econ 45(2):287-303

Bavarsad B, Sinaei H, Delavaripour J (2013) Study on the Relationship between Financial Constraints and Stock Return in Tehran Stock Exchange. International Journal of Economy, Management and Social Science 2 No. May, 166-173

Bhaduri SN (2005) Investment, financial constraints and financial liberalization: some stylized facts from a developing economy, India. J Asian Econ 16(4):704-718

Bhaumik SK, Das PK, Kumbhakar SC (2012) A stochastic frontier approach to modelling financial constraints in firms: An application to India. J Bank Financ 36(5):1311-1319

Bo, H, Lensink, R, \& Sterken E (2003) Uncertainty and financing constraints. Review of Finance 7(2):297-321

Bond S, Meghir CHD (1994) Dynamic investment models and the firm's financial policy. Review of economic studies, no. February 1994. https://doi.org/10.2307/2297978

Byun HY, Choi S, Hwang LS, Kim RG (2013) Business group affiliation, ownership structure, and the cost of debt. J Corp Finan 23:311-331

Campello M, Graham J, Harvey C (2010) The real effects of financial constraints: evidence from a financial crisis. J Financ Econ 97(3):470-487

Carpenter RE, Fazzari SM, \& Petersen BC (1998) Financing constraints and inventory investment: A comparative study with high-frequency panel data. Review of Economics and Statistics 80(4):513-519

Chapman DR, Junor CW, Stegman TR (1996) Cash flow constraints and firms' investment behaviour. Appl Econ 28(8):1037-1044

Chirinko RS, Schaller H (1995) Why does liquidity matter in investment equations? J Money Credit Bank 27(2):527-548

Cleary S (1999) The relationship between firm investment and financial status. J Financ 54(2):673-692

Cleary S (2006) International corporate investment and the relationships between financial constraint measures. Journal of Banking and Finance 30(5):1559-1580

Craney TA, Surles JG (2002) Model-dependent variance inflation factor cutoff values. Qual Eng 14(3):391-403

Črnigoj M, Verbič M (2014) Financial constraints and corporate investments during the current financial and economic crisis: The credit crunch and investment decisions of Slovenian firms. Econ Syst 38(4):502-517

Dasgupta S, \& Sengupta K (2007) Corporate liquidity, investment and financial constraints: Implications from a multiperiod model. Journal of Financial Intermediation 16(2):151-174

Denis DJ, Sibilkov V (2010) Financial constraints, investment, and the value of cash holdings. Rev Financ Stud 23(1):247-269

Devereux M, Schiantarelli, F (1990) Investment, financial factors, and cash row: evidence from U.K. panel data. In Asymmetric information, corporate finance, and investment, University of Chicago Press, January, pp 279-306. http://www.nber.org/papers/w3116

Erickson T, Whited TM (2000) Measurement error and the relationship between investment and q. J Polit Econ 108(5): $1027-1057$

Fazzari SM, Hubbard RG, Petersen BC (1988) Financing constraints and corporate investment. Brook Pap Econ Act $(1,1): 141-206$

Gilchrist S, Himmelberg CP (1995) Evidence on the role of cash flow for investment. J Monet Econ 36(3):541-572

Hoshi T, Kashyap A, Scharfstein D (1991) Corporate structure, liquidity, and investment: evidence from Japanese industrial groups. Q J Econ 106(1):33-60

Hubbard RG, Kashyap AK, Whited TM (1995) Internal Finance and Firm Investment. J Money, Credit Bank 27(3), 683-702

Kadapakkam PR, Kumar P, Riddick LA (1998) The impact of cash flows and firm size on investment: the international evidence. J Bank Financ 22(3):293-320

Kaplan SN, Zingales L (1995) Do financing constraints explain why investment is correlated with cash flow? (no. w5267). In: National Bureau of economic research

Lamont O, Polk C, Saá-Requejo J (2001) Financial constraints and stock returns. Rev Financ Stud 14(2):529-554

Lensink R, der Molen R, Gangopadhyay S (2003) Business groups, financing constraints and investment: the case of India. J Dev Stud 40(2):93-119

Modigliani F, Miller M (1958) The cost of capital, corporation finance and the theory of investment. Am Econ Rev 48(3):261-297

Sargan JD (1958) The estimation of economic relationships using instrumental variables. Econometrica: Journal of the Econometric Society 26(3):393-415

Schaller H (1993) Asymmetric information, liquidity constraints, and Canadian investment. Can J Econ 26(3):552-574

Shin HH, Park YS (1999) Financing constraints and internal capital markets: evidence from Koreanchaebols. J Corp Finan 5(2):169-191

Stucki T (2014) Success of start-up firms: the role of financial constraints. Ind Corp Chang 23(1):25-64

Wang HJ (2003) A stochastic frontier analysis of financing constraints on investment: the case of financial liberalization in Taiwan. J Bus Econ Stat 21(3):406-419

Whited T (1992) Debt, liquidity constraints, and corporate investment: evidence from panel data. J Financ 47(4):1425-1460

Whited TM, Wu G (2006) Financial constraints risk. Rev Financ Stud 19(2):531-559 